DOI 10.18551/rjoas.2019-03.14

\title{
THE ROLE OF GENDER DIVERSITY ON THE BOARD OF DIRECTORS AND TAX AVOIDANCE
}

\author{
Prasetyo Nugroho Budi \\ Faculty of Economic and Business, University of Airlangga, Indonesia \\ E-mail: nugrohobudi32@gmail.com
}

\begin{abstract}
This research discusses how the role of the diversity gender of the board directors related to the prospect theory and the previous research that stated that women has a risk averse nature. The data that is used in this research come from all sectors of the company in Indonesia Stock Exchange excluding financial company in 2012 - 2017 with a total of observation 1399 samples. The analysis technique which is used in this research is regression linear method analysis with the help of STATA 14.0 software. Gender diversity on the director boards is a variable which will be tested whether it will affect the tax avoidance with several control variables. The result of the regression shows that gender diversity does not have any influence on tax avoidance. The additional testing is done by performing four interaction tests between independent variable with the variable of independent board, audit committee, big 4 auditor, and blockheld. The result indicates that there are not any tests which signify that gender diversity on the director boards affects tax avoidance. This result happened because of the companies which possess the high proportion of director boards does not necessarily have high ETR as well, so that it can be concluded that not all women have risk averse nature. This can be associated with the theory of liberal feminism that states women do not want to be distinguished from men except in terms of gender.
\end{abstract}

\section{KEY WORDS}

Gender diversity, tax avoidance, prospect theory, liberal feminism.

The development of tax ratio to Gross Domestic Product (GDP) in Indonesia tends to be flat since 2008, explained by the Minister of Finance Sri Mulyani in International Tax Conference in Jakarta in July 2017. Based on the report launched by International Monetary Fund (IMF), tax ratio to GDP of Indonesia is in the percentage of $12 \%$, which is far from average of the other ASEAN countries which 15,4\%. The low ratio number depicts the level of compliance of tax payment is low as well, this means the tax payers in Indonesia is still not obedient in paying tax.

The system which used in Indonesia in order to count and pay the tax is selfassessment system, which regulates the tax payers do the counting and reporting the tax on their own. This system very depends on the obedience of the tax payers because the paid tax is considered correct until the government can prove that it is wrong, moreover the optimal surveillance from tax apparatus. That flaw can be used by the tax payers to avoid tax. The most common way used by the company is by claiming "loss" in their financial report, because tax payers are taxed on profit.

Moreover, the situation is worse because of the existence of panama papers which is a document of Mossak Fonsesca, a law firm centered in Panama City and has 42 branches in the world; most of them located in tax haven countries that the document was leaked to the public through journalists of press in Germany and the document was provided free of charge to the International Consortium of Investigative Journalists (ICIJ). There are several figures in Indonesia who are registered as Mossack Fonsesca clients and more than 2000 names. The incident triggered a tax amnesty program from the government to obtain funds from tax evaders.

The practice of tax avoidance in the company is not immune from the supervision of company managers so that the practice is carried out by an independent board of commissioners and independent board of directors included the corporate governance 
component (corporate governance). They are expected to provide a supervisory function related to company activities

The practice of tax avoidance in the company is not immune from the supervision of company managers so that the practice is carried out legally and does not violate applicable regulations. Supervision of the practice is carried out by an independent board of commissioners and independent board of directors included in the corporate governance component (corporate governance). They are expected to provide a supervisory function related to company activities, one of them is the practice of tax avoidance. However, the party who plays a major role in decision making is the company's board of directors. They hold full power over the management of company operations including corporate tax decisions. One component of corporate governance that can influence a company's tax avoidance action is the gender diversity of the board of directors.

The previous research finds the relationship between gender diversity of board directors and the tax aggressiveness. Boussaidi and Hamed (2015) find that gender diversity has significantly affected the effective tax rate (ETR) in Tunisia; the high ETR value indicates the low level of tax avoidance. The research of Lanis et al. (2015), which discusses about gender diversity and the tax aggressiveness of companies in United States, finds the negative connection between the gender diversity and tax aggressiveness. It shows that varied board directors diminish the level of tax aggressiveness of the company. The similar result is also found in the research of Richardson et al (2016) that spoke about the presence of women in the board directors and tax aggressiveness in Australia.

Gender diversity in the board directors has some impact in corporate governance, especially in making decision. Adams and Ferreira (2009) found the relationship between the presence of woman in board directors to the performance of the company and the corporate governance. They see that board directors that have more gender variation are better supervisors, better boards in making decision, and woman board directors generally are more concerned about ethical problems (Chen et al., 2017)

Based on the explanation above, it can be concluded that there are still many tax evasion practiced by the companies in Indonesia. Referring to the previous research, with the corporate governance component in the form of gender diversity of board directors, it is expected to reduce that practice. This research took a period starting from 2012 because at that time the financial report of public companies in Indonesia started to implement International Financial Reporting Standards (IFRS) until 2017, the last year of provided financial statement when this research was conducted and in order to see latest tax evasion of companies.

\section{LITERATURE REVIEW}

In terms of the relationship of gender diversity with the competitive advantage of companies, there are several differences of opinion in the literature. Gender diversity is believed to provide benefits to the companies because women are considered to have "feelings" (Krishnan \& Park, 2005). The values and advantages of "feelings" provide harmony, prioritize information disclosure, provide solutions to existing conflicts, and show more democratic leadership (Hurst et al., 1989; Earley \& Mosakowski, 2000; Eagly \& Johnson, 1990).

The board of directors of women is also assumed to be "strong" because they always experience obstacles in maintaining their position on the board of directors which are generally monopolized by men, and this provides psychological benefits, and good interaction between directors (Pettigrew, 2001). Increased creativity and innovation will be achieved when gender diversity occurs within the board of directors (Campbell \& MinguezVera, 2008).

Research by Lanis et al. (2015) used the proportion of female board of directors as a proxy for the board's gender diversity variable. The percentage of women is also a proxy for gender diversity in other studies (Bousaidi and Hamed, 2015; Khoula and Ali, 2012; Chen et 
al., 2017). Therefore this study also uses the percentage or proportion of women on the board of directors as a measurement of variables.

Previous research on gender diversity of the board of directors conducted by Betz et al. (1989) found that women's board of directors tended to be risk averse (avoiding risk) compared to the board of directors related to the writing of the company's financial statements. Peni and Vähämaa (2010) found that companies that have a female Chief Financial Officer (CFO) do financial reporting that is more conservative and risk averse compared to male CFOs. Francis et al. (2014) analyzed the influence of the CFO's gender on tax aggressiveness. They found that female CFOs had fewer or lower levels of relationship with tax avoidance due to their risk averse nature.

In general, women's board of directors show more independent thinking than men, which is important in carrying out effective supervision as a task of the board of commissioners (Carter et al., 2003). Daily et al. (2000) found that women gave different views on the board of commissioners and provided more transparency. Women also have a positive influence and increase trust of stakeholder in the board of commissioners (Heminway, 2007). Srinidhi et al. (2011) examined whether companies in United States that have a diverse board of directors (gender) show better quality of earnings. They found that gender diversity on the board of directors will have deeper discussions, look for and find solutions to difficult problems, which are usually "left" by the board of directors is partly or entirely composed of men. They observed that the oversight capacity of the board of directors increased through more detailed board discussions and better communication between the boards, this is due to the presence of women on the board. Gul et al. (2011) conducted research related to companies in the United States. The research analyzed whether gender diversity in the board of directors had an impact on more transparent and specific company stock information. They say that the gender diversity of the board of directors can increase the discussion that occurs on the board of directors and can also increase the ability of the board of directors to conduct transactions with strict supervision, disclosure, and reporting, as well as careful consideration in decision making.

In tax, women are more obedient in financial statement compared to men (Baldry, 1987). Ruegger and King (1992) found that in many problems happened; gender diversity affected the changing attitude related to tax. Fallan (1999) conducted research to find the difference of decision making affected by the level of the person's knowledge about tax.

The explanation above indicates that woman conducts more strict and efficient supervision like the independent board. Moreover, women also tend to be risk averse, have better moral, ethics, independent thinking, and transparent decision; and decrease the stakeholder's trust to the board. Hence, the presence of women in the boards of directors is expected to decrease the company's tax avoidance. Hypothesis that can be formulated in this research is:

$\mathrm{H} 1$ : The presence of women in boards of directors affects negatively to the tax avoidance.

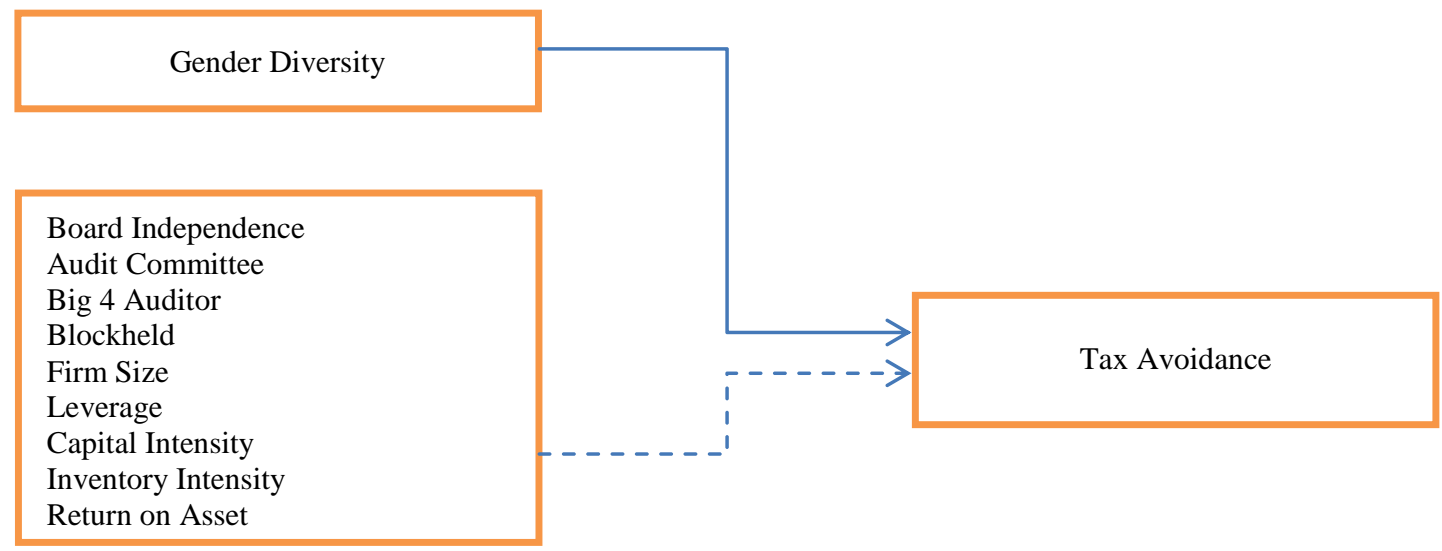

Figure 1 - Conceptual Framework 


\section{METHODS OF RESEARCH}

The population in this study were public companies listed on the Indonesia Stock Exchange (IDX) for the period 2012 - 2017. The method of sampling in this study was conducted by purposive sampling with the criteria of (1) non-financial public companies listed on the IDX; (2) firms with negative income; (3) firms that have NOL carry-forwards; (4) firms with ETRs exceeding one and (5) firms with missing data.

The mathematical model used to test the hypotheses developed in this study follows Lanis et al. (2015):

$$
\begin{gathered}
\text { CURRENTETR }_{i t}=\beta_{0}+\beta_{1} \text { WOMEN }_{i t}+\beta_{2} \text { BOARDIND }_{\text {it }}+\beta_{3} \text { ACSIZE }_{i t}+\beta_{4} \text { BIG }_{i t}+\beta_{5} \text { BLOCK }_{i t}+ \\
\beta_{6} \text { FSIZE }_{i t}+\beta_{7} \text { LEV }_{i t}+\beta_{8} \text { CAPINT }_{\text {it }}+\beta_{9} \text { INVINT }_{i t}+\beta{ }_{0} \text { ROA }_{i t}+\varepsilon_{i t}
\end{gathered}
$$

The dependent variable of this study is the tax avoidance that is proxied by current ETR (Hanlon \& Heitzman, 2010) with the following formula:

$$
\text { Current ETR }=\frac{\text { current income tax expense }}{\text { pre }- \text { tax accounting income }}
$$

Independent variable of this study is proxied by the percentage of women in the board of directors composition, while the control variables in this study are:

- Board Independence (BOARDIND). This variable controls the difference in independence on the board of directors and board of commissioners with the presence of independent directors. This variable controls the difference in independence on the board of directors and board of commissioners with the presence of independent directors;

- Audit Committee (ACSIZE). This variable controls the difference in the number of audit committees within a company. The audit committee is described as a monitoring mechanism to improve the monitoring function in internal control, company compliance, and relevant and reliable financial reports. ACSIZE is measured as the number of audit committee members in the company;

- Big 4 Auditor (BIG4). This variable controls the difference in ability and audit quality between big 4 auditors and other auditors (Matsumura \& Tucker, 1992). Clients from big 4 auditors should have a lower level of tax aggressiveness. BIG4AUD is measured as a dummy variable, coded 1 if the company uses big auditor services 4 , 0 if it does not;

- Blockheld (BLOCK). This variable controls the difference in shareholding by the shareholders who have at least $5 \%$ shares and are not related to management. Shareholders can help to oversee management because they have larger influence on the board of commissioners and management than a shareholder who has less than $5 \%$ share (Shleifer \& Vishny, 1986). BLOCK is measured as the total proportion of ordinary shares owned by shareholders whose numbers are at least $5 \%$.

$$
B L O C K=\frac{\text { shares owned by the shareholder }}{\text { number of shares outstanding }}
$$

- Firm Size (SIZE). Company size is a scale in classifying the size of a company. Large companies can achieve economies of scale through tax planning (Rego, 2003). SIZE is measured as a result of the logarithm of total assets;

- Leverage (LEV). Leverage explains the relationship between the uses of funds obtained from debt. Companies that have a lot of debt have low ETR value because interest expense will reduce the tax costs incurred by the company (Noor \& Fadzillah, 2010). LEV is measured as total debt divided by total assets;

- Capital Intensity (CAPINT) and Inventory Intensity (INVINT). CAPINT is positively related to tax aggressiveness due to high depreciation rates. CAPINT is measured as 
net property, plant, and equipment divided by total assets. INVINT is a substitute for CAPINT, so companies with inventory intensity should not avoid taxes, so INVINT is negatively related to tax aggressiveness (Stickney \& McGee, 1982). INVINT is measured as inventory divided by total assets;

- Return on Asset (ROA). ETR measurement is influenced by how the company is able to generate profits, and then ETR is directly proportional to the company's ability to generate profits. The higher ROA will increase ETR, so ROA is positively related to tax aggressiveness (Kim \& Zhang, 2016). This variable is measured as pre-tax profit divided by total assets.

\section{RESULT OF STUDY}

Based on data from the Indonesia Stock Exchange, a total of 1399 observation from 2012-2017.

Table 1 - Descriptive Statistics

\begin{tabular}{ccccc}
\hline Variable & Mean & Median & Minimum & Maximum \\
\hline CURRENTETR & 0.236 & 0.241 & 0.000 & 0.911 \\
WOMEN & 0.132 & 0.000 & 0.000 & 0.800 \\
BOARDIND & 0.273 & 0.273 & 0.000 & 0.667 \\
ACSIZE & 3.043 & 3.000 & 0.000 & 6.000 \\
BIG4 & 0.412 & 0.000 & 0.000 & 1.000 \\
BLOCK & 0.700 & 0.719 & 0.000 & 0.994 \\
LEV & 1.052 & 0.760 & 0.000 & 6.530 \\
ROA & 0.076 & 0.056 & 0.000 & 0.402 \\
SIZE & 12.393 & 12.400 & 10.678 & 13.965 \\
CAPINT & 0.305 & 0.268 & 0.000 & 0.906 \\
INVINT & 0.164 & 0.135 & 0.000 & 0.672 \\
\hline
\end{tabular}

Source: Data processed, 2018.

In this study, one independent variable and nine control variables were used to provide information about the results of the interaction between the independent variable and the dependent variable. Based on the descriptive statistics table above, the proxy for aggressive tax is represented through the CURRENTETR variable. In the descriptive statistics above, it can be shown the minimum value of the CURRENTETR variable owned by the sample used in the study of 0 . The maximum value is 0.911 , and the median value of the variable CURRENTETR is 0.241 . The average value of CURRENTETR is 0.236 .

Pearson Correlation is used to see the relationship between two variables and measure the strength of the relationship between the two variables. The results of the Pearson correlation test are shown in table 2. The table shows the coefficient value of the relationship between two variables and the level of significance in the variables in the study. Significance levels are marked with $a{ }^{*}$ sign on its coefficient value. According to Pearson Correlation in the table above, the WOMEN variable has a positive and significant relationship with the BLOCK and INVINT variables, while having a negative and significant relationship with the ACSIZE, BIG4, LEV, and SIZE variables.

The OLS regression in table 3 shows the regression results between variable of tax avoidance (CURRENTETR) on the gender diversity of the board of directors (WOMEN) with several control variables. The results of regression above include industry and fixed effects in order to reduce differences in regression results between years and between industries in regression testing. The results in table 4.3 show that the gender diversity of the board of commissioners does not have a significant effect on tax avoidance with a coefficient of 0.025 and a significance value of 0.296 that exceeds the $10 \%$ significance level. Furthermore, the control variables BOARDIND, ACSIZE, BIG4, CAPINT have a significant positive effect on tax avoidance, while ROA and SIZE have a significant negative effect on tax avoidance. BLOCK and LEV do not have a significant effect on tax avoidance. 
Table 2 - Pearson Correlation

\begin{tabular}{|c|c|c|c|c|c|c|c|c|c|c|c|}
\hline & CURRENTETR & WOMEN & BOARDIND & ACSIZE & BIG4 & BLOCK & LEV & $\mathrm{ROA}$ & SIZE & CAPINT & INVINT \\
\hline CURRENTETR & 1.000 & & & & & & & & & & \\
\hline WOMEN & $\begin{array}{l}0.011 \\
(0.683)\end{array}$ & 1.000 & & & & & & & & & \\
\hline BOARDIND & $\begin{array}{l}0.073^{-1} \\
(0.006)\end{array}$ & $\begin{array}{l}0.017 \\
(0.514)\end{array}$ & 1.000 & & & & & & & & \\
\hline ACSIZE & $\begin{array}{l}0.005 \\
(0.840)\end{array}$ & $\begin{array}{l}-0.083^{3} \\
(0.002)\end{array}$ & $\begin{array}{l}-0.064 \\
(0.017)\end{array}$ & 1.000 & & & & & & & \\
\hline BIG4 & $\begin{array}{l}0.080^{1} \\
(0.003)\end{array}$ & $\begin{array}{l}-0.094 \\
(0.000)\end{array}$ & $\begin{array}{l}-0.142 \\
(0.000)\end{array}$ & $\begin{array}{l}0.134 \\
(0.000)\end{array}$ & 1.000 & & & & & & \\
\hline BLOCK & $\begin{array}{l}0.049^{\prime} \\
(0.066)\end{array}$ & $\begin{array}{l}0.068^{\prime \prime} \\
(0.011)\end{array}$ & $\begin{array}{l}-0.037 \\
(0.169)\end{array}$ & $\begin{array}{l}-0.086 \\
(0.001)\end{array}$ & $\begin{array}{l}0.085^{1 \times} \\
(0.001)\end{array}$ & 1.000 & & & & & \\
\hline LEV & $\begin{array}{l}0.025 \\
(0.360)\end{array}$ & $\begin{array}{l}-0.085^{2} \\
(0.001)\end{array}$ & $\begin{array}{l}-0.010 \\
(0.697)\end{array}$ & $\begin{array}{l}0.012 \\
(0.644)\end{array}$ & $\begin{array}{l}0.032 \\
(0.238)\end{array}$ & $\begin{array}{l}0.037 \\
(0.168)\end{array}$ & 1.000 & & & & \\
\hline ROA & $-0.153^{l * m}$ & 0.017 & -0.024 & $0.057^{-1 .}$ & $0.190^{2+x}$ & 0.025 & $-\overline{0.159^{* * *}}$ & 1.000 & & & \\
\hline SIZE & $\begin{array}{l}(0.000) \\
-0.101\end{array}$ & $\begin{array}{l}(0.522) \\
-0.117\end{array}$ & $\begin{array}{l}(0.378) \\
-0.158\end{array}$ & $\begin{array}{l}(0.034) \\
0.202\end{array}$ & $\begin{array}{l}(0.000) \\
0.427\end{array}$ & $\begin{array}{l}(0.346) \\
0.182\end{array}$ & $\begin{array}{l}(0.000) \\
0.089\end{array}$ & $0.076^{\cdots \cdots}$ & 1.000 & & \\
\hline & $(0.000)$ & $(0.000)$ & $(0.000)$ & $(0.000)$ & $(0.000)$ & $(0.000)$ & $(0.001)$ & $(0.004)$ & & & \\
\hline CAPINT & 0.138 & -0.039 & 0.015 & $0.049^{\prime}$ & $0.058^{* 1}$ & $0.045^{\prime}$ & -0.013 & $0.075^{*+* t}$ & -0.044 & 1.000 & \\
\hline INVINT & $\begin{array}{l}(0.000) \\
0.060^{*}\end{array}$ & $\begin{array}{l}(0.145) \\
0.055\end{array}$ & $\begin{array}{l}(0.576) \\
-0.042\end{array}$ & $\begin{array}{l}(0.067) \\
-0.052\end{array}$ & $\begin{array}{l}(0.029) \\
-0.008\end{array}$ & $\begin{array}{l}(0.094) \\
0.038\end{array}$ & $\begin{array}{l}(0.636) \\
0.064^{*}\end{array}$ & $\begin{array}{l}(0.005) \\
0.029\end{array}$ & $\begin{array}{l}(0.099) \\
- \\
0.131\end{array}$ & $-0.270^{* * *}$ & 1.000 \\
\hline & $(0.025)$ & $(0.039)$ & $(0.117)$ & $(0.051)$ & $(0.757)$ & $(0.160)$ & $(0.017)$ & $(0.286)$ & $(0.000)$ & $(0.000)$ & \\
\hline
\end{tabular}

Source: Data processed, 2018.

Table 3 - Hypothesis Test Results Effect of Gender Diversity on Tax Avoidance

\begin{tabular}{|c|c|c|}
\hline & Coefficient & $\begin{array}{c}\text { CURRENTETR } \\
\mathrm{P}\end{array}$ \\
\hline WOMEN & $\begin{array}{l}0.025 \\
(1.04)\end{array}$ & 0.296 \\
\hline BOARDIND & $\begin{array}{l}0.170^{\cdots} \\
(3.60)\end{array}$ & 0,000 \\
\hline ACSIZE & $\begin{array}{l}0.017^{\circ} \\
(1.91)\end{array}$ & 0,057 \\
\hline BIG4 & $\begin{array}{l}0.026^{\circ} \\
(2.65)\end{array}$ & 0,008 \\
\hline BLOCK & $\begin{array}{l}-0.009 \\
(-0.39)\end{array}$ & 0,694 \\
\hline LEV & $\begin{array}{l}0.002 \\
(0.49)\end{array}$ & 0,626 \\
\hline ROA & $\begin{array}{l}-0.435 \\
(-7.62)\end{array}$ & 0,000 \\
\hline SIZE & $\begin{array}{l}-0.017^{*} \\
(-2.31)\end{array}$ & 0,021 \\
\hline CAPINT & $\begin{array}{l}0.036^{\circ} \\
(1.69)\end{array}$ & 0,091 \\
\hline INVINT & $\begin{array}{l}0.033 \\
(1.13)\end{array}$ & 0,259 \\
\hline _cons & $\begin{array}{l}0.247 \\
(1.40)\end{array}$ & \\
\hline Fixed effects - Industry & Yes & \\
\hline Fixed effects - Year & Yes & \\
\hline $\begin{array}{l}\mathrm{r} 2 \\
\mathrm{~N}\end{array}$ & & $\begin{array}{l}0.204 \\
1399 \\
\end{array}$ \\
\hline
\end{tabular}

Source: Data processed, 2018.

Furthermore, the authors conducted a further regression analysis to see the effect of the gender diversity of the board of directors on tax avoidance in companies listed on the Indonesia stock exchange. The next development in seeing the influence of gender diversity on board of directions is by conducting interaction. The author conducted four interactions, namely: (1) the interaction of gender diversity of the board of directors with an independent board on tax avoidance; (2) the interaction of the gender diversity of the board of directors with the number of audit committees on tax avoidance; (3) the interaction of gender diversity of the board of directors with the big 4 public accounting firm on tax avoidance; (4) the interaction of gender diversity of the board of directors with blockhelds on tax avoidance. 
Independent boards, audit committees, big 4 auditors, and block holders have a similar role to the company, namely the role of supervision. This interaction will see whether the relationship between gender diversity of the board of directors and tax avoidance is getting stronger or weaker.

Table 4 - Additional Test Results With Board Independence Interaction

\begin{tabular}{lll}
\hline & \multicolumn{2}{l}{ Dependentt: CURRENT ETR } \\
& OLS & Robust Regression \\
\hline WOMEN_BOARDIND & 0.120 & 0.120 \\
& $(0.47)$ & $(0.47)$ \\
WOMEN & -0.009 & -0.009 \\
& $(-0.12)$ & $(-0.13)$ \\
BOARDIND & 0.154 & 0.154 \\
& $(2.68)$ & $(2.09)$ \\
Control Variables & Included & Included \\
Fixed effects - Industry & Included & Included \\
Fixed effects - Year & Included & Included \\
\hline r2 & 0.192 & 0.192 \\
$N$ & 1399 & 1399 \\
\hline
\end{tabular}

Source: Data Processed, 2018.

Table 5 - Additional Test Results With Audit Committe Interaction

\begin{tabular}{lll}
\hline & \multicolumn{2}{l}{ Dependentt: CURRENT ETR } \\
& OLS & Robust Regression \\
\hline WOMEN_ACSIZE & 0.011 & 0.011 \\
& $(0.23)$ & $(0.19)$ \\
WOMEN & -0.009 & -0.009 \\
& $(-0.06)$ & $(-0.05)$ \\
ACSIZE & 0.016 & 0.016 \\
& $(1.50)$ & $(1.59)$ \\
Control Variables & Included & Included \\
Fixed effects - Industry & Included & Included \\
Fixed effects - Year & Included & Included \\
\hline r2 & 0.203 & 0.203 \\
$N$ & 1399 & 1399 \\
\hline
\end{tabular}

Source: Data Processed, 2018.

Table 6 - Additional Test Results With Big 4 Auditor Interaction

\begin{tabular}{lll}
\hline & \multicolumn{2}{l}{ Dependentt: CURRENT ETR } \\
& OLS & Robust Regression \\
\hline WOMEN_BIG4 & -0.048 & -0.048 \\
WOMEN & $(-0.96)$ & $(-0.96)$ \\
& 0.038 & 0.038 \\
BIG4 & $(1.39)$ & $(1.26)$ \\
& $0.032^{\pi \times x}$ & $0.032^{\times \pi}$ \\
Control Variables & $(2.74)$ & $(2.51)$ \\
Fixed effects - Industry & Included & Included \\
Fixed effects - Year & Included & Included \\
r2 & Included & Included \\
$N$ & 0.204 & 0.204 \\
\hline
\end{tabular}

Source: Data Processed, 2018.

Table 7 - Additional Test Results With Blockheld Interaction

\begin{tabular}{lll}
\hline & Dependentt: CURRENT ETR \\
& OLS & Robust Regression \\
\hline WOMEN_BLOCK & 0.046 & 0.046 \\
WOMEN & $(0.33)$ & $(0.33)$ \\
& -0.009 & -0.009 \\
BLOCK & $(-0.08)$ & $(-0.08)$ \\
& -0.014 & -0.014 \\
Control Variables & $(-0.51)$ & $(-0.50)$ \\
Fixed effects - Industry & Included & Included \\
Fixed effects - Year & Included & Included \\
\hline r2 & Included & Included \\
$N$ & 0.203 & 0.203 \\
\hline
\end{tabular}

Source: Data Processed, 2018. 
Based on the results of the regression conducted to examine the influence of the gender diversity of the board of directors on tax avoidance, it shows that there is no significant influence on the board's gender diversity on tax avoidance. Even with interaction model shown in table 4 to 7 , gender diversity on the board of directors still doesn't have an effect on tax avoidance.

Previous research which says that women have the risk averse nature cannot be proven in this study. The nature of a woman's risk averse as a board of directors should be indicated by a high ETR value because the board of directors who want to avoid risk should not want to do tax avoidance but on the data collected the authors did not say that. This means that it is in line with the theory of liberal feminism that requires that women be totally integrated in all roles, equal to men and do not want any role differences. This theory can mean that women do not always have a risk nature and can also have a risk taker character, according to the data collected by the author where there is a low ETR value even though the proportion of female board of directors is high.

\section{CONCLUSION}

The main theories used in this study are prospect theory and liberal feminism theory. The conclusion that can be taken from the result of OLS regression and some additional tests are that gender diversity on the board of directors does not affect firm's tax avoidance. The ETR value of the firms doesn't affected by the proportion of women in the board of directors, meaning that higher proportion of women doesn't always has a higher ETR value. Higher ETR value means low of tax avoidance activities.

The limitations of this study are that focuses only on the influence of the gender diversity of the board of directors on tax avoidance by using only one proxy that is current ETR. The suggestions for further reasearch are to use another proxies of tax avoidance, and use another variables that can reduce firm's tax avoidance.

\section{REFERENCES}

1. Adams, R. B., \& Ferreira, D. (2009). Women in the boardroom and their impact on governance and performance. Journal of financial economics, 94(2), 291-309.

2. Baldry, J. C. (1987). Income tax evasion and the tax schedule: Some experimental results. Public Finance= Finances publiques, 42(3), 357-383.

3. Betz, M., O'Connell, L., \& Shepard, J. M. (1989). Gender differences in proclivity for unethical behavior. Journal of Business Ethics, 8(5), 321-324.

4. Boussaidi, A., \& Hamed, M. S. (2015). The impact of governance mechanisms on tax aggressiveness: empirical evidence from Tunisian context. Journal of Asian Business Strategy, 5(1),

5. Campbell, K., \& Mínguez-Vera, A. (2008). Gender diversity in the boardroom and firm financial performance. Journal of business ethics, 83(3), 435-451.

6. Carter, D. A., Simkins, B. J., \& Simpson, W. G. (2003). Corporate governance, board diversity, and firm value. Financial review, 38(1), 33-53.

7. Chen, L. H., Gramlich, J., \& Houser, K. A. (2017). The Effects of Board Gender Diversity on a Firm's Risk Strategies. Accounting \& Finance.

8. Daily, C. M., Certo, S. T., \& Dalton, D. R. (2000). The future of corporate women Women on corporate boards of directors (pp. 11-23): Springer.

9. Dharmasaputra, M. (2013). Saksi Kunci. Jakarta: Tempo.

10. Eagly, A. H., \& Johnson, B. T. (1990). Gender and leadership style: A meta-analysis. Psychological bulletin, 108(2), 233.

11. Earley, C. P., \& Mosakowski, E. (2000). Creating hybrid team cultures: An empirical test of transnational team functioning. Academy of Management Journal, 43(1), 26-49.

12. Fallan, L. (1999). Gender, exposure to tax knowledge, and attitudes towards taxation; an experimental approach. Journal of Business Ethics, 18(2), 173-184. 
13. Francis, B. B., Hasan, I., Wu, Q., \& Yan, M. (2014). Are female CFOs less tax aggressive? Evidence from tax aggressiveness. The Journal of the American Taxation Association, 36(2), 171-202.

14. Gul, F. A., Srinidhi, B., \& Ng, A. C. (2011). Does board gender diversity improve the informativeness of stock prices? Journal of Accounting and Economics, 51(3), 314-338.

15. Heminway, J.M. (2007). Sex, trust, and corporate boards. Hastings Women's LJ, 18, 173.

16. Hurst, D. K., Rush, J. C., \& White, R. E. (1989). Top management teams and organizational renewal. Strategic Management Journal, 10(S1), 87-105.

17. Kim, C. F., \& Zhang, L. (2016). Corporate political connections and tax aggressiveness. Contemporary Accounting Research, 33(1), 78-114.

18. Krishnan, H. A., \& Park, D. (2005). A few good women-on top management teams. Journal of business research, 58(12), 1712-1720.

19. Lanis, R., Richardson, G., \& Taylor, G. (2015). Board of director gender and corporate tax aggressiveness: an empirical analysis. Journal of Business Ethics, 144(3), 577-596.

20. Matsumura, E. M., \& Tucker, R. R. (1992). Fraud detection: A theoretical foundation. Accounting Review, 753-782.

21. Noor, R. M., \& Fadzillah, N. S. M. (2010). Corporate tax planning: A study on corporate effective tax rates of Malaysian listed companies. International Journal of Trade, Economics and Finance, 1(2), 189.

22. Peni, E., \& Vähämaa, S. (2010). Female executives and earnings management. Managerial Finance, 36(7), 629-645.

23. Pettigrew, A. M. (2001). Commentary on the Donald Hambrick interview. Academy of Management Executive, 15(3), 42-44.

24. Rego, S. O. (2003). Tax-avoidance activities of US multinational corporations. Contemporary Accounting Research, 20(4), 805-833.

25. Richardson, G., \& Lanis, R. (2016). Women on the board of directors and corporate tax aggressiveness in Australia: An empirical analysis. Accounting Research Journal, 29(3), 313-331.

26. Ruegger, D., \& King, E. W. (1992). A study of the effect of age and gender upon student business ethics. Journal of Business Ethics, 11(3), 179-186.

27. Shleifer, A., \& Vishny, R. W. (1986). Large shareholders and corporate control. Journal of political economy, 94(3, Part 1), 461-488.

28. Srinidhi, B., Gul, F. A., \& Tsui, J. (2011). Female directors and earnings quality. Contemporary Accounting Research, 28(5), 1610-1644.

29. Stickney, C. P., \& McGee, V. E. (1982). Effective corporate tax rates the effect of size, capital intensity, leverage, and other factors. Journal of accounting and public policy, 1(2), 125-152. 